\title{
Stability of Fruit Quality Traits of Different Strawberry Varieties under Variable Environmental Conditions
}

\author{
Lucía Cervantes ${ }^{1,2}$, María Teresa Ariza ${ }^{1}$, Luis Miranda ${ }^{3}$, David Lozano ${ }^{4}$, Juan Jesús Medina ${ }^{5}$ \\ Carmen Soria ${ }^{1}$ and Elsa Martínez-Ferri ${ }^{1, *}$ iD \\ 1 IFAPA Centro de Málaga, Junta de Andalucía, Cortijo de la Cruz s/n, 29140 Churriana, Málaga, Spain \\ lucia.cervantes@juntadeandalucia.es (L.C.); mariat.ariza@juntadeandalucia.es (M.T.A.); \\ maria.soria@juntadeandalucia.es (C.S.) \\ 2 Universidad de Málaga, Ftad. Ciencias, Campus de Teatinos s/n, 29071 Málaga, Spain \\ 3 IFAPA Centro Las Torres, Junta de Andalucía, Ctra. Sevilla-Cazalla Km. 12.2, 41200 Sevilla, Spain; \\ luis.miranda.enamorado@juntadeandalucia.es \\ 4 IFAPA Centro de Alameda del Obispo, Junta de Andalucía, Avenida Menéndez Pidal S/N, \\ 14004 Córdoba, Spain; david.lozano@juntadeandalucia.es \\ 5 IFAPA Centro de Huelva, Junta de Andalucía, Julio Caro Baroja s/n, 21002 Huelva, Spain; \\ juanj.medina@juntadeandalucia.es \\ * Correspondence: elsa.martinez@juntadeandalucia.es
}

Received: 31 July 2020; Accepted: 20 August 2020; Published: 23 August 2020

\begin{abstract}
Strawberry fruit quality traits can be affected by genotype-environment interactions, determining the final consumer acceptance of fruits. Trait stability under varying environments is necessary to ensure the fruit quality of strawberries selected by breeding programs. Hence, inter- and intra-annual variation of organoleptic and functional fruit quality parameters of five strawberry varieties throughout four consecutive cropping seasons was analyzed to assess their relative stability. In most varieties, organoleptic parameters showed higher inter-annual stability but greater variability throughout the season, while the reverse was true for the functional quality parameters. Relative humidity and mean and minimum temperatures partially accounted for fruit quality variation but other factors along with the genotype may also have an influence. Among the varieties, 'Splendor' displayed greater year-on-year stability in organoleptic parameters, and 'Sabrina' and Candonga ${ }^{\circledR}$ showed higher inter- and intra-annual stability on functional fruit quality, respectively. Environmental variation did not affect fruit quality parameters similarly in all strawberry varieties. In 'Sabrina' and Candonga ${ }^{\circledR}$ antioxidant capacity (TEAC) was greater and stable throughout the cropping season, underlining TEAC as a tool for varietal selection, and suggesting these two varieties as parents for breeding programs that seek healthy features and high-quality fruits that meet consumer demands.
\end{abstract}

Keywords: Fragaria $\times$ ananassa; fruit quality variability; environmental variation; genotype

\section{Introduction}

Fruits and vegetables are an important part of the daily diet since they provide essential nutrients and fibers [1]. This is the case of strawberry fruits, highly appreciated by consumers due to their texture, aroma and flavor (i.e., organoleptic fruit quality). In addition to its organoleptic properties, epidemiological studies attribute certain benefits against different diseases to strawberries, due to the presence of various bioactive compounds (i.e., functional fruit quality) [2,3], mainly antioxidants of polyphenolic nature, enhancing its demand for consumption.

However, strawberry cultivation includes a wide range of varieties as a result of several breeding programs developed throughout the world to obtain genotypes adapted to the agroclimatic conditions 
of specific areas. For this reason, not all strawberry varieties present the same fruit quality [4-6] and they do not respond in the same way to the variation of environmental factors such as incident light, temperature and relative humidity $[7,8]$. Thus, it is known that changes in environmental conditions determine the development of strawberry plants, affecting flowering, fruiting and fruit quality, among other characteristics [7,9]. Furthermore, in specific situations, climatic conditions can be a source of stress for the crop depending on the ability of the varieties to cope with it. In this sense, it has been described that antioxidant compounds of polyphenolic nature play an important role in the general mechanisms of response to different stressors and, therefore, changes in environmental variables could be expected to influence the composition and synthesis of these compounds in different parts of the plant, including fruits [10].

Thus, both the quantity and the quality of the incident light can affect biosynthesis and the accumulation of different phytochemical compounds at the fruit level (i.e., sugars, carotenoids, phenolic acids or anthocyanins), and their effect depends on the species and cultivar [11]. More specifically, a low incidence of light directly reduces photosynthesis and, therefore, the synthesis of sugars and carbohydrates, and vitamin C $[12,13]$, affecting fruit quality.

Changes in temperature affect both the production and the quality of strawberry fruits. Low temperatures (below $7^{\circ} \mathrm{C}$ ) increase the incidence of misshapen fruits, alterations in fruit size and color $[4,14]$. On the other hand, high temperatures decrease the photosynthetic rate of the plant by up to $44 \%$, compromising crop yield [15] and causing a decrease in sugars at the fruit level and, consequently, in sweetness [14]. However, slightly elevated temperatures could induce the synthesis of phenolic compounds, including anthocyanins, leading to redder and darker fruits [14-16], thereby increasing the antioxidant capacity of the fruits and their functional quality [17].

The air relative humidity is closely related to the temperature and it conditions the evaporative demand and the transpiration of the plant both at the leaf and fruit level. Therefore, it directly affects their water content, size and the concentration of bioactive compounds. Currently, there are few studies analyzing the effect of this variable on the quality of fruits and vegetables [18], although a negative correlation with the antioxidant capacity of the fruits has been found in strawberries, especially in rainy periods [17].

Therefore, the variation of environmental factors can affect - to a different extent-the organoleptic and functional quality of the fruits in the different strawberry genotypes $[19,20]$, and, consequently, their acceptance by the consumers.

In this sense, numerous breeding programs seek to develop new strawberry varieties, well adapted to the agroclimatic conditions of a specific area, with high yield and fruit quality [21-24]. However, although genotype selection in these breeding programs involves the study of advanced selections over several years, to date, few comprehensive approaches regarding the relative contribution of genotypic and environmental factors to the organoleptic and functional quality of the fruits are available $[19,20,25]$. Additionally, it is unknown to what extent these fruit quality traits remain stable throughout the changing environmental conditions during the cropping season and between different years (intra- and inter-annual environmental variation, respectively).

Thus, in the productive area of Huelva, contrasting environmental conditions between the early and late cropping season are differentiated. In the early season (between January and March), photoperiod is shorter, light incidence and temperatures are lower and relative humidity is higher whereas the reverse is true for the late season (between April and May). These environmental differences throughout the season may involve that the same variety could have fruits of different quality depending on the time of harvest. This would depend on the sensitivity of the different varieties to environmental changes and on the stability of its fruit quality parameters. Hence, those varieties with high and stable fruit quality (organoleptic and functional) throughout the cropping season could be selected as parents in breeding programs aiming for new strawberry varieties with higher fruit quality attributes. 
The present work aims to assess the effect of intra- and inter-annual environmental variation in the organoleptic and functional fruit quality of five strawberry varieties widely cultivated in the conventional cropping conditions of the Huelva area in order to determine their relative fruit quality stability.

\section{Materials and Methods}

\subsection{Plant Material and Experimental Design}

An experiment was carried out during 4 consecutive cropping seasons (2011-2012 (2012), 2012-2013 (2013), 2013-2014 (2014) and 2014-2015 (2015)) at the IFAPA experimental farm "El Cebollar" $\left(37^{\circ} 08^{\prime} 52^{\prime \prime} \mathrm{N}, 6^{\circ} 47^{\prime} 28^{\prime \prime} \mathrm{O}, 63 \mathrm{~m}\right.$ high), in Moguer, Huelva (Spain). This area has a Mediterranean-type climate, with dry and warm summers and moderately cold winters. On each season, plants from five short-day strawberry varieties: Candonga ${ }^{\circledR}$, 'Fortuna', 'Primoris', 'Sabrina' and 'Splendor' were arranged in a complete randomized block design with three replicate plots per cultivar and 50 plants per plot. On each season, plants were propagated during summer at high-elevation nurseries in Castilla-Leon (north-eastern Spain; lat. $41^{\circ} 30^{\prime} \mathrm{N}$, long. $4^{\circ} 55^{\prime} \mathrm{W}$, alt. $900-1200 \mathrm{~m}$ a.s.l.) where chilling requirements for strawberry cold hardening are provided (i.e., 150-200 $\mathrm{h}$ at $\mathrm{T}<7^{\circ} \mathrm{C}$ ) [26]. In mid-October, plants were transplanted into a double row mulched raised beds $(35 \mathrm{~cm}$ high and $50 \mathrm{~cm}$ wide) spaced at $25 \times 25 \mathrm{~cm}$ on sandy soil with $5.8 \%$ clay, $5 \%$ silt and $89.2 \%$ sand, $0.09 \%$ organic matter, $0.25 \mathrm{dS} \mathrm{m}^{-1} \mathrm{EC} 1-2.5,<1 \%$ active $\mathrm{CaCO}_{3}$ and a $\mathrm{pH}$ of 5.4 (saturated soil extract in 1:2.5 soil:H2O). Prior to planting, the soil was solarized and biofumigated (biosolarization) [27], to reduce the presence of soil pathogens and irrigated with $\approx 650 \mathrm{~m}^{3} \mathrm{ha}^{-1}$. Plants were cultivated following conventional cropping practices [26] and polyethylene-covered tunnel structures (macrotunnel) [7] were installed in mid-November and removed at the end of the cropping season (late May).

Fruit set takes place from January (mid-winter) to the end of May (late spring), involving that fruit set and ripening occur under different environmental conditions during the cropping season. For the analyses of the organoleptic and functional fruit quality parameters throughout the cropping season, mature fruit samples of all varieties and repetitions were taken in three harvest times (mid-February, mid-March and mid-April) on each season. Fruits with homogeneous reddish color were selected as mature fruits.

Daily data of temperature $\left({ }^{\circ} \mathrm{C}\right)$, relative humidity $(\%)$ and incident solar radiation $\left(\mathrm{MJ} \mathrm{m}^{-2} \mathrm{day}^{-1}\right)$ were obtained from a weather station installed inside the macrotunnel and belonging to the Andalusian Agroclimatic Information Network (RIA) [28].

\subsection{Fruit Quality Analysis}

\subsubsection{Organoleptic Parameters}

The organoleptic parameters measured were firmness, acidity and total soluble solids content (TSS). Firmness was measured by a penetrometer with a $3.5 \mathrm{~mm}$ diameter hammer on 6 fruits per repetition. Each fruit was measured twice in two opposite sides of the equatorial zone. The results obtained were expressed in $\mathrm{kg} / \mathrm{cm}^{2}$.

Samples of $\sim 250 \mathrm{~g}$ of ripe fruits (i.e., $8-10$ fruits per plot) were immediately homogenized with a mixer to obtain a puree for carrying out the remaining quality analyses. The acidity was measured by titrating $1 \mathrm{~g}$ of puree diluted in $100 \mathrm{~mL}$ distilled water to $\mathrm{pH} 8.1$ with $0.01 \mathrm{M} \mathrm{NaOH}$ on a Titroline Easy pH meter (Schott Instruments ${ }^{\circledR} \mathrm{GmbH}$, Mainz, Germany). Acidity was expressed as g of citric acid per $100 \mathrm{~g}$ of fresh fruit weight (FW). The TSS was measured in an aliquot of this puree with a refractometer (PR-32 $\alpha$, Atago, Japan) and expressed in ${ }^{\circ}$ Brix. The rest of the puree was stored at $-20{ }^{\circ} \mathrm{C}$ for the subsequent analysis of the functional quality parameters. 


\subsubsection{Functional Parameters}

Quantification of vitamin C was performed using test strips on a reflectometer (Rqflex 10, Merck KGaA, Darmstadt, Germany) from $1 \mathrm{~g}$ of puree diluted in $10 \mathrm{~mL}$ of distilled water. The results obtained were expressed in $\mathrm{mg}$ of ascorbic acid per $100 \mathrm{~g}$ FW.

The analysis of the polyphenol content was carried out from a hydrometanolic extraction. Briefly, $2 \mathrm{~g}$ of puree was diluted in $10 \mathrm{~mL}$ of methanol: $\mathrm{HCl}$ (99.9:0.01), incubated at $4{ }^{\circ} \mathrm{C}$ for $24 \mathrm{~h}$ and then it was centrifuged at $10,000 \mathrm{rpm}$ for $15 \mathrm{~min}$ at $4{ }^{\circ} \mathrm{C}$. The supernatant was diluted in the same extraction solvent (2:1) and stored at $-20^{\circ} \mathrm{C}$ until the time of analysis.

The total phenol content (TPC) of the hydrometanolic extract was determined by the Folin-Ciocalteu method [29], modified by Tulipani et al. [30]. Hence, Folin-Ciocalteu reagent $(200 \mu \mathrm{L}), \mathrm{Na}_{2} \mathrm{CO}_{3}(400 \mu \mathrm{L}, 35 \% \mathrm{w} / \mathrm{v})$ and 50-fold diluted extract $(2 \mathrm{~mL})$ were mixed and incubated $1 \mathrm{~h}$ at room temperature in the dark. The absorbance at $725 \mathrm{~nm}$ was measured on a spectrophotometer (Shimadzu UV-1700, PharmaSpec Inc., WA, USA,). Gallic acid was used as standard and results were expressed in mg of gallic acid equivalents (GAE) per $100 \mathrm{~g}$ FW.

The total flavonoid content (TFC) was determined as in Dewanto et al. [31]. Briefly, $250 \mu \mathrm{L}$ of the hydrometanolic extract was taken and mixed with $1.25 \mathrm{~mL}$ of MilliQ water and $75 \mu \mathrm{L}$ of $5 \% \mathrm{NaNO}_{2}$. After $6 \min 150 \mu \mathrm{L}$ of $10 \% \mathrm{AlCl}_{3} 6 \mathrm{H}_{2} \mathrm{O}$ was added and incubated for 5 min. Finally, $500 \mu \mathrm{L}$ of $\mathrm{NaOH}$ $(1 \mathrm{M})$ and $275 \mu \mathrm{L}$ of MilliQ water were added and the absorbance was measured at $510 \mathrm{~nm}$. Catechin was used as standard, and the results were expressed in mg of catechin (CAE) per $100 \mathrm{~g}$ FW.

Total anthocyanin content (TAC) was measured according to the differential $\mathrm{pH}$ method [32], whereby a solution at $\mathrm{pH} 1(\mathrm{KCl} 0.025 \mathrm{M})$ and another at $\mathrm{pH} 4.5\left(\mathrm{CH}_{3} \mathrm{CO}_{2} \mathrm{Na} 0.4 \mathrm{M}\right)$ were used to prepare two different dilutions $(1: 10 v / v)$ of the hydrometanolic extract. These mixtures were incubated in the dark for $15 \mathrm{~min}$ and their absorbance was measured at $500 \mathrm{~nm}$ and $700 \mathrm{~nm}$. The final total absorbance (AbsT) was calculated as:

$$
\text { AbsT }=(A b s 500 \mathrm{~nm}-\mathrm{Abs700} \mathrm{nm)} \mathrm{pH} 1.0-(\text { Abs500 nm - Abs700 nm) pH } 4.5
$$

The total anthocyanin content was calculated as follows:

$$
\text { Anthocyanin content }=(\mathrm{AbsT} \times \mathrm{MW} \times \mathrm{fd} \times 1000) /(\varepsilon \times 1)
$$

where:

MW: molecular weight of the reference anthocyanin (perlangonidine-3-glucoside).

fd: Sample dilution factor

$\varepsilon$ : molar extinction coefficient of perlangonidine-3-glucoside. The result was expressed in $\mathrm{mg}$ of pelargonidin-3-glucoside equivalent (PE) per $100 \mathrm{~g}$ FW.

For the determination of the antioxidant capacity, new extracts were obtained by mixing $2.8 \mathrm{~g}$ of puree in $10 \mathrm{~mL}$ of $60 \%$ methanol. The samples were centrifuged at $3000 \mathrm{rpm}$ for $15 \mathrm{~min}$ at $4{ }^{\circ} \mathrm{C}$. The supernatant was stored at $-20^{\circ} \mathrm{C}$ until antioxidant capacity (TEAC) analysis (Trolox Equivalent Antioxidant Capacity) [33]. Briefly, an ABTS + radical solution was prepared by mixing $7 \mathrm{mM}$ aqueous ABTS• + solution with $2.45 \mathrm{mM} \mathrm{K}_{2} \mathrm{~S}_{2} \mathrm{O}_{8}$, and incubated in the dark for $12 \mathrm{~h}$. Before performing the analysis, the working solution was prepared by diluting $1.15 \mathrm{~mL}$ of ABTS• + radical solution with $100 \mathrm{~mL}$ of ethanol. Then, $1 \mathrm{~mL}$ of this mixture was added to $10 \mu \mathrm{L}$ of sample and after 1-3 min the absorbance at $734 \mathrm{~nm}$ was determined and the percentage of color inhibition of the ABTS $\bullet+$ radical by the sample was calculated:

$$
\% \text { inhibition }=(\text { Abscontrol }- \text { Abssample } / \text { Abscontrol }) \times 100
$$

where: Abscontrol: absorbance at $734 \mathrm{~nm}$ of a water sample.

Trolox reagent was used as standard and results were expressed as $\mu$ moles of trolox equivalent (TE) per g FW. 


\subsection{Statistical Analysis}

Statistical analyses were carried out with STATISTICA 7.0 analytical software (Stat Sotf Inc., Tulsa, OK, USA). To assess the effects of the 'variety', 'year' and 'harvest time' and their interaction on the fruit quality parameters, a CRBD analysis of variance (ANOVA) was performed in which 'variety' was considered as 'between-subjects' factor and 'year' and 'harvest time' were 'within subjects' factors. When significant interactions between 'variety' and the other factors were observed, the effect of 'year' and 'harvest time' on fruit quality was analyzed separately for each variety (two-way ANOVA). For comparison among varieties within a 'year' or 'harvest time', data sets were subjected to one-way ANOVA. Assumptions of normality and homogeneity were tested by the Shapiro-Wilk's and Cochran's $\mathrm{C}$ tests, respectively.

To assess the relationship between environmental variables and the fruit quality parameters, Pearson's correlations and stepwise multiple regression [34,35] were performed. Data from each harvest time were plotted against averaged data of daily minimum and maximum temperature, percentage of relative humidity and radiation of the 10 days before fruit picking. This period was selected considering that most of the metabolic changes associated with ripening from white to red fruit occur around 10 days prior to harvest [36].

\section{Results and Discussion}

This study reports an integrative analysis of the intra- and inter- annual stability of organoleptic and functional fruit quality traits on different strawberry genotypes and their specific relationship with the environmental variation. In this work, it is shown that both the genotype and the environmental variation occurring between and within cropping seasons in the productive area of Huelva (Table 1) influence the organoleptic and functional fruit quality.

Table 1. Averaged values of the environmental variables measured under the macro-tunnel on the 10 days before fruit sampling on four consecutive years (2012-2015) and at three harvest times (February, March and April). Different letters indicate significant differences between years, each month $(p<0.05)$.

\begin{tabular}{|c|c|c|c|c|c|c|c|c|c|c|c|c|}
\hline & \multicolumn{4}{|c|}{ February } & \multicolumn{4}{|c|}{ March } & \multicolumn{4}{|c|}{ April } \\
\hline \multicolumn{13}{|c|}{ Maximum Temperature $\left(\operatorname{Tmax} ;{ }^{\circ} \mathrm{C}\right)$} \\
\hline 2012 & 15.15 & \pm & 0.72 & ns & 21.78 & \pm & 0.58 & a & 18.85 & \pm & 0.97 & $b$ \\
\hline 2013 & 15.96 & \pm & 0.43 & ns & 17.04 & \pm & 0.43 & $b$ & 26.69 & \pm & 0.66 & $\mathrm{a}$ \\
\hline 2014 & 15.67 & \pm & 0.38 & ns & 22.18 & \pm & 0.74 & $\mathrm{a}$ & 21.20 & \pm & 1.65 & $\mathrm{~b}$ \\
\hline 2015 & 16.06 & \pm & 0.41 & ns & 21.01 & \pm & 1.09 & a & 21.59 & \pm & 0.8 & $\mathrm{~b}$ \\
\hline \multicolumn{13}{|c|}{ Minimum Temperature $\left(\mathrm{Tmin} ;{ }^{\circ} \mathrm{C}\right)$} \\
\hline 2012 & 0.43 & \pm & 0.95 & C & 5.37 & \pm & 0.57 & ns & 8.12 & \pm & 0.83 & $\mathrm{~b}$ \\
\hline 2013 & 3.67 & \pm & 0.65 & $\mathrm{~b}$ & 7.59 & \pm & 1.07 & ns & 11.72 & \pm & 0.70 & $\mathrm{a}$ \\
\hline 2014 & 7.94 & \pm & 1.21 & $a$ & 6.51 & \pm & 0.37 & ns & 9.90 & \pm & 0.81 & $a b$ \\
\hline 2015 & 6.36 & \pm & 0.58 & $\mathrm{a}$ & 5.3 & \pm & 0.42 & ns & 11.33 & \pm & 0.39 & $\mathrm{a}$ \\
\hline \multicolumn{13}{|c|}{ Mean Temperature (Tmed; $\left.{ }^{\circ} \mathrm{C}\right)$} \\
\hline 2012 & 7.52 & \pm & 0.8 & C & 12.98 & \pm & 0.36 & $a b$ & 13.45 & \pm & 0.62 & $c$ \\
\hline 2013 & 9.63 & \pm & 0.36 & $b$ & 11.88 & \pm & 0.59 & b & 18.71 & \pm & 0.56 & $\mathrm{a}$ \\
\hline 2014 & 11.77 & \pm & 0.68 & $\mathrm{a}$ & 13.83 & \pm & 0.33 & $a b$ & 15.51 & \pm & 1.00 & $\mathrm{~b}$ \\
\hline 2015 & 11.31 & \pm & 0.32 & $\mathrm{a}$ & 12.61 & \pm & 0.42 & $a b$ & 15.80 & \pm & 0.39 & $\mathrm{~b}$ \\
\hline \multicolumn{13}{|c|}{ Relative Humidity (RH; \%) } \\
\hline 2012 & 50.55 & \pm & 4.60 & $\mathrm{c}$ & 60.47 & \pm & 4.23 & c & 73.65 & \pm & 3.49 & ns \\
\hline 2013 & 68.57 & \pm & 2.44 & $\mathrm{~b}$ & 78.45 & \pm & 3.82 & a & 72.45 & \pm & 2.57 & ns \\
\hline 2014 & 85.61 & \pm & 4.10 & $\mathrm{a}$ & 66.63 & \pm & 3.11 & $\mathrm{bc}$ & 81.16 & \pm & 3.06 & ns \\
\hline 2015 & 73.92 & \pm & 3.59 & $\mathrm{~b}$ & 74.36 & \pm & 3.04 & $\mathrm{ab}$ & 76.98 & \pm & 2.43 & ns \\
\hline \multicolumn{13}{|c|}{ Radiation $\left(\mathrm{mJ} / \mathrm{m}^{2}\right)$} \\
\hline 2012 & 15.8 & \pm & 0.24 & $a$ & 20.46 & \pm & 0.47 & a & 19.44 & \pm & 1.65 & $b$ \\
\hline 2013 & 14.76 & \pm & 0.41 & $a$ & 15.26 & \pm & 1.85 & b & 23.88 & \pm & 0.71 & $\mathrm{a}$ \\
\hline 2014 & 9.32 & \pm & 1.85 & $b$ & 20.07 & \pm & 0.65 & a & 19.18 & \pm & 1.71 & $b$ \\
\hline 2015 & 10.93 & \pm & 1.19 & $\mathrm{~b}$ & 19.37 & \pm & 1.47 & a & 18.22 & \pm & 1.6 & $b$ \\
\hline
\end{tabular}


This was evidenced by the overall significant effect of the 'variety', 'year' and 'harvest time' in the fruit quality parameters analyzed (Tables 2 and 3). Although previous works $[19,20,37,38]$ have described an interactive effect between genotype and environment on the quality of strawberry fruits, no comprehensive studies have performed a comparative analysis of the relative stability of organoleptic and functional traits to the environmental variation occurring between different years (inter-annual) and during crop development (intra-annual) in different strawberry varieties.

During the study period, average temperature and relative humidity values in the 10 days before fruit harvesting were lower in 2012 than in the other seasons whereas 2014 and 2015 displayed similar environmental conditions (Table 1). Higher year-on-year variability was observed in February in comparison with the other months. Only mid- and late-season values of maximum temperature and incident radiation differed significantly in 2013 from the other seasons (Table 1).

It should be noted that the range of environmental variation did not translate into values of fruit quality out of the range described for strawberry in the literature [30,39-41]. Thus, values of fruit firmness, acidity, soluble solids (TSS) and TSS/acidity, ranged from $179-583 \mathrm{~kg} / \mathrm{cm}^{2}, 0.53-0.98 \mathrm{mg} / 100 \mathrm{~g}$ FW, 5.5-9.9 ${ }^{\circ}$ Brix and 7-14, respectively. Similarly, functional fruit quality parameters including the content of total phenols, total flavonoids, total anthocyanins, vitamin $C$ and antioxidant capacity, displayed values between 77-304 mg GAE/100 g FW, 9-67 mg CAE/100 g FW, 10-26 mg PE/100 g FW, 33-88 mg ascorbic acid/100 g FW and 17-65 $\mu \mathrm{mol} \mathrm{TE/g} \mathrm{FW,} \mathrm{respectively.} \mathrm{Among} \mathrm{varieties,} \mathrm{there} \mathrm{were}$ significant differences in most of the parameters evaluated except in flavonoid content and TEAC (Table 2).

The year-on-year variation in environmental conditions observed in our study did not necessarily involve variability in all the organoleptic and functional fruit quality parameters nor all varieties (Table 2). Thus, fruit quality parameters in 'Sabrina' were more stable than in the rest of the varieties, displaying significant inter-annual variation only in three out of the nine fruit quality parameters evaluated (i.e., total content of phenols, total flavonoids and antioxidant capacity; Table 2). The rest of the varieties showed a different degree of inter-annual variability depending on the parameter considered.

Regarding organoleptic fruit quality parameters, it should be noted that firmness and TSS did not show significant inter-annual variation in any of the study varieties. Only acidity in 'Fortuna' and TSS/acidity in 'Primoris' showed a significant inter-annual variation. In general, these results are pointing out great stability of the organoleptic fruit quality parameters in the range of year-on-year environmental variation of our study, consistently with the preservation of the varietal selection features of their respective breeding programs.

In contrast, there was great inter-annual variability in most of the functional quality parameters in all varieties, with the exception of the anthocyanins content in all varieties, and vitamin C in 'Sabrina' (Table 2), suggesting that the magnitude of the year-on-year environmental changes is enough to induce different levels of antioxidants in the varieties studied. These results are consistent with previous studies [19] and with the involvement of polyphenols in the plant response to environmental changes, as it has been reported in several Mediterranean plant species exposed to multiple and simultaneous environmental stresses [20,42]. The activation of biosynthesis and the accumulation of different polyphenolic compounds in the different tissues occur after the onset of different protective/defense mechanisms (i.e., response to excess light, salinity or drought) [42]. It should be noted that differences among varieties in the content of polyphenols did not translate into a different antioxidant capacity (TEAC), supporting that, in addition to polyphenols and vitamin C, other types of compounds with antioxidant characteristics must be contributing to TEAC in the different varieties. This parameter integrates the antioxidant processes of the fruits [43-45] and has been suggested as an indicator of fruit healthy properties [46-48] and as a tool for varietal selection in breeding programs seeking for healthy features. 
Table 2. Inter-annual variation of the organoleptic and functional fruit quality parameters in the five strawberry varieties. Each value is the mean \pm SE for each year regardless of the harvest time. Lowercase letters indicate significant differences between years on each variety, and capital letters indicate significant differences between varieties $(p<0.05)$.

\begin{tabular}{|c|c|c|c|c|c|c|c|c|c|c|c|c|c|c|c|c|c|c|c|c|}
\hline & \multicolumn{4}{|c|}{ Candonga $\AA$} & \multicolumn{4}{|c|}{ 'Splendor' } & \multicolumn{4}{|c|}{ 'Fortuna' } & \multicolumn{4}{|c|}{ 'Primoris' } & \multicolumn{4}{|c|}{ 'Sabrina' } \\
\hline \multicolumn{21}{|c|}{ Firmness $\left(\mathrm{Kg} / \mathrm{cm}^{2}\right)$} \\
\hline 2012 & 438.1 & \pm & 38.3 & ns & 341.7 & \pm & 49.3 & ns & 402.6 & \pm & 24.9 & ns & 449.2 & \pm & 38.8 & ns & 475.3 & \pm & 45.3 & ns \\
\hline 2013 & 343.3 & \pm & 58.2 & ns & 287.8 & \pm & 63.3 & ns & 334.8 & \pm & 37.6 & ns & 386.1 & \pm & 69.8 & ns & 383.1 & \pm & 72.4 & ns \\
\hline 2014 & 403.9 & \pm & 30.0 & ns & 318.1 & \pm & 55.2 & ns & 376.8 & \pm & 39.9 & ns & 449.9 & \pm & 50.5 & ns & 446.3 & \pm & 25.5 & ns \\
\hline 2015 & 413.4 & \pm & 62.8 & ns & 324.7 & \pm & 56.5 & ns & 356.2 & \pm & 47.7 & ns & 419.9 & \pm & 73.0 & ns & 449.1 & \pm & 77.8 & ns \\
\hline Average & 399.7 & \pm & 23.5 & $\mathrm{C}$ & 318.1 & \pm & 24.7 & E & 367.6 & \pm & 18.0 & $\mathrm{D}$ & 426.3 & \pm & 26.6 & B & 438.5 & \pm & 27.2 & A \\
\hline \multicolumn{21}{|c|}{ TSS $\left({ }^{\circ}\right.$ Brix $)$} \\
\hline 2012 & 8.63 & \pm & 0.77 & ns & 7.04 & \pm & 0.15 & ns & 7.29 & \pm & 0.54 & ns & 8.43 & \pm & 0.54 & ns & 7.84 & \pm & 0.70 & ns \\
\hline 2013 & 8.18 & \pm & 0.86 & ns & 6.13 & \pm & 0.20 & ns & 7.34 & \pm & 0.61 & ns & 7.61 & \pm & 1.13 & ns & 7.40 & \pm & 1.01 & ns \\
\hline 2014 & 7.30 & \pm & 0.51 & ns & 7.20 & \pm & 0.32 & ns & 6.83 & \pm & 0.44 & ns & 8.03 & \pm & 0.51 & ns & 7.59 & \pm & 0.27 & ns \\
\hline 2015 & 9.05 & \pm & 0.24 & ns & 7.31 & \pm & 0.47 & ns & 7.83 & \pm & 0.34 & ns & 8.00 & \pm & 0.72 & ns & 7.31 & \pm & 0.27 & ns \\
\hline Average & 8.29 & \pm & 0.34 & A & 6.92 & \pm & 0.19 & $\mathrm{C}$ & 7.32 & \pm & 0.24 & B & 8.02 & \pm & 0.34 & A & 7.53 & \pm & 0.28 & $\mathrm{~B}$ \\
\hline \multicolumn{21}{|c|}{ Acidity (mg cítric acid/100 g FW) } \\
\hline 2012 & 0.77 & \pm & 0.03 & ns & 0.68 & \pm & 0.01 & ns & 0.59 & \pm & 0.03 & $\mathrm{~b}$ & 0.62 & \pm & 0.03 & ns & 0.67 & & 0.06 & ns \\
\hline 2013 & 0.74 & \pm & 0.02 & ns & 0.68 & \pm & 0.04 & ns & 0.60 & \pm & 0.02 & $\mathrm{~b}$ & 0.70 & \pm & 0.05 & ns & 0.72 & \pm & 0.05 & ns \\
\hline 2014 & 0.84 & \pm & 0.07 & ns & 0.73 & \pm & 0.03 & ns & 0.72 & \pm & 0.03 & a & 0.76 & \pm & 0.05 & ns & 0.82 & \pm & 0.02 & ns \\
\hline 2015 & 0.82 & \pm & 0.07 & ns & 0.78 & \pm & 0.05 & ns & 0.70 & \pm & 0.01 & a & 0.80 & \pm & 0.07 & ns & 0.80 & \pm & 0.07 & ns \\
\hline Average & 0.79 & \pm & 0.02 & A & 0.72 & \pm & 0.02 & $\mathrm{C}$ & 0.65 & \pm & 0.02 & $\mathrm{D}$ & 0.72 & \pm & 0.03 & $\mathrm{C}$ & 0.76 & \pm & 0.03 & $\mathrm{~B}$ \\
\hline \multicolumn{21}{|c|}{ TSS/acidity } \\
\hline 2012 & 11.28 & \pm & 1.21 & ns & 10.44 & \pm & 0.38 & ns & 12.35 & \pm & 0.58 & ns & 13.65 & \pm & 0.17 & a & 11.72 & & 0.70 & ns \\
\hline 2013 & 10.81 & \pm & 0.84 & ns & 9.03 & \pm & 0.40 & ns & 12.22 & \pm & 0.53 & ns & 10.70 & \pm & 0.93 & $\mathrm{~b}$ & 10.20 & \pm & 0.83 & ns \\
\hline 2014 & 8.85 & \pm & 1.02 & ns & 9.87 & \pm & 0.15 & ns & 9.62 & \pm & 0.96 & ns & 10.63 & \pm & 0.87 & $\mathrm{~b}$ & 9.22 & \pm & 0.33 & ns \\
\hline 2015 & 11.27 & \pm & 1.04 & ns & 9.39 & \pm & 0.66 & ns & 11.24 & \pm & 0.56 & ns & 10.06 & \pm & 0.26 & $\mathrm{~b}$ & 9.26 & \pm & 0.76 & ns \\
\hline Average & 10.55 & \pm & 0.54 & B & 9.68 & \pm & 0.24 & $\mathrm{C}$ & 11.36 & \pm & 0.44 & A & 11.26 & \pm & 0.51 & A & 10.10 & \pm & 0.42 & $\mathrm{BC}$ \\
\hline \multicolumn{21}{|c|}{ Total Phenolic Content (mg GAE/100 g FW) } \\
\hline 2012 & 128.1 & \pm & 15.8 & c & 114.2 & \pm & 17.8 & $\mathrm{~b}$ & 91.4 & \pm & 10.5 & c & 116.0 & \pm & 7.9 & $\mathrm{~b}$ & 121.0 & \pm & 15.3 & $\mathrm{~b}$ \\
\hline 2013 & 249.1 & \pm & 21.3 & a & 218.5 & \pm & 18.4 & a & 204.3 & \pm & 13.8 & $\mathrm{ab}$ & 220.7 & \pm & 38.6 & a & 201.4 & \pm & 44.7 & $\mathrm{a}$ \\
\hline 2014 & 264.1 & \pm & 9.00 & a & 224.8 & \pm & 12.1 & a & 212.7 & \pm & 5.3 & $\mathrm{a}$ & 264.0 & \pm & 20.2 & a & 223.6 & \pm & 1.7 & $\mathrm{a}$ \\
\hline 2015 & 221.5 & \pm & 10.8 & $\mathrm{~b}$ & 229.2 & \pm & 4.30 & a & 174.2 & \pm & 6.3 & $\mathrm{~b}$ & 220.9 & \pm & 10.9 & a & 181.1 & \pm & 9.2 & $\mathrm{a}$ \\
\hline Average & 215.7 & \pm & 17.2 & A & 196.7 & \pm & 15.6 & B & 170.6 & \pm & 15.0 & $\mathrm{D}$ & 205.4 & \pm & 19.1 & $\mathrm{~B}$ & 181.8 & \pm & 15.4 & $\mathrm{C}$ \\
\hline \multicolumn{21}{|c|}{ Total Flavonoid Content (mg CAE/100 g FW) } \\
\hline 2012 & 15.84 & \pm & 1.50 & $\mathrm{~b}$ & 12.84 & \pm & 0.51 & b & 12.77 & \pm & 1.08 & $\mathrm{~b}$ & 15.88 & \pm & 1.15 & $\mathrm{~b}$ & 11.79 & \pm & 0.99 & $\mathrm{~b}$ \\
\hline 2013 & 16.38 & \pm & 1.79 & $\mathrm{~b}$ & 13.68 & \pm & 0.61 & $\mathrm{~b}$ & 13.29 & \pm & 1.30 & $\mathrm{~b}$ & 15.62 & \pm & 0.59 & $\mathrm{~b}$ & 11.26 & \pm & 1.10 & $\mathrm{~b}$ \\
\hline 2014 & & & & & & & & & & & & & & & & & & & & \\
\hline 2015 & 54.96 & \pm & 4.97 & a & 46.62 & \pm & 4.29 & a & 41.87 & \pm & 2.14 & a & 57.40 & \pm & 4.72 & a & 42.27 & \pm & 2.28 & $\mathrm{a}$ \\
\hline Average & 29.06 & \pm & 6.67 & NS & 24.38 & \pm & 5.70 & NS & 22.64 & \pm & 4.87 & NS & 29.63 & \pm & 7.08 & NS & 21.78 & \pm & 5.18 & NS \\
\hline & & & & & Total A & ntho & ocyani & Cont & $t(\mathrm{mg} \mathrm{P}$ & $/ 100$ & $\mathrm{ggFW}$ & & & & & & & & & \\
\hline 2012 & 16.48 & \pm & 3.28 & ns & 21.51 & \pm & 2.68 & ns & 19.09 & \pm & 3.33 & ns & 14.25 & \pm & 2.09 & ns & 15.22 & \pm & 4.55 & ns \\
\hline 2013 & 16.13 & \pm & 1.21 & ns & 19.56 & \pm & 1.60 & ns & 23.05 & \pm & 2.77 & ns & 16.24 & \pm & 2.32 & ns & 16.80 & \pm & 2.37 & ns \\
\hline 2014 & 17.29 & \pm & 0.53 & ns & 18.35 & \pm & 0.86 & ns & 21.12 & \pm & 1.71 & ns & 15.63 & \pm & 2.82 & ns & 20.15 & \pm & 1.78 & ns \\
\hline 2015 & 14.75 & \pm & 0.20 & ns & 22.21 & \pm & 1.72 & ns & 21.31 & \pm & 1.72 & ns & 15.15 & \pm & 2.04 & ns & 19.52 & \pm & 1.53 & ns \\
\hline Average & 16.16 & \pm & 0.80 & $\mathrm{C}$ & 20.41 & \pm & 0.91 & A & 21.14 & \pm & 1.14 & A & 15.32 & \pm & 1.02 & $\mathrm{D}$ & 17.92 & \pm & 1.35 & $\mathrm{~B}$ \\
\hline & & & & & & & TEAC & $\mu \mathrm{mol}$ & $\mathrm{E} / \mathrm{g} \mathrm{FW}$ & & & & & & & & & & & \\
\hline 2012 & 55.20 & \pm & 2.27 & a & 56.04 & \pm & 4.68 & a & 38.14 & \pm & 5.57 & a & 49.76 & \pm & 4.03 & a & 46.57 & & 1.56 & $\mathrm{a}$ \\
\hline 2013 & 47.16 & & 5.05 & $a b$ & 36.84 & \pm & 6.60 & $\mathrm{~b}$ & 35.99 & \pm & 11.1 & a & 43.62 & \pm & 7.90 & a & 32.97 & & 0.99 & $\mathrm{bc}$ \\
\hline 2014 & 38.64 & \pm & 2.76 & bc & 32.62 & \pm & 4.24 & $\mathrm{~b}$ & 32.61 & \pm & 4.45 & $\mathrm{~b}$ & 29.74 & \pm & 7.75 & $\mathrm{~b}$ & 38.66 & \pm & 1.41 & $\mathrm{~b}$ \\
\hline 2015 & 31.56 & \pm & 3.84 & c & 28.72 & \pm & 3.16 & $\mathrm{~b}$ & 25.46 & \pm & 5.04 & c & 27.27 & \pm & 3.74 & $\mathrm{~b}$ & 28.54 & \pm & 3.45 & c \\
\hline Average & 43.14 & \pm & 3.10 & NS & 38.55 & \pm & 3.78 & NS & 33.05 & \pm & 3.34 & NS & 37.60 & \pm & 3.87 & NS & 36.68 & \pm & 2.22 & NS \\
\hline & & & & & & $\min$ & $\mathrm{C}(\mathrm{m}$ & ascor & acid $/ 1$ & $0 \mathrm{~g} \mathrm{~F}$ & FW) & & & & & & & & & \\
\hline 2012 & 58.11 & \pm & 3.96 & $\mathrm{~b}$ & 52.28 & \pm & 3.11 & $\mathrm{~b}$ & 42.67 & \pm & 1.00 & $\mathrm{~b}$ & 54.11 & & 2.11 & $\mathrm{~b}$ & 52.11 & & 2.00 & ns \\
\hline 2013 & 54.67 & \pm & 3.67 & $\mathrm{~b}$ & 46.44 & \pm & 2.04 & $\mathrm{~b}$ & 43.78 & \pm & 1.87 & $\mathrm{~b}$ & 49.39 & \pm & 5.47 & $\mathrm{~b}$ & 47.22 & & 5.39 & ns \\
\hline 2014 & 45.67 & \pm & 4.00 & $\mathrm{~b}$ & 44.67 & \pm & 4.00 & $\mathrm{~b}$ & 37.92 & \pm & 0.42 & $\mathrm{~b}$ & 38.17 & \pm & 4.83 & $\mathrm{~b}$ & 40.83 & \pm & 5.83 & ns \\
\hline 2015 & 75.50 & \pm & 6.40 & a & 70.44 & \pm & 5.86 & a & 62.00 & \pm & 5.74 & a & 72.00 & \pm & 6.33 & a & 63.67 & \pm & 9.43 & ns \\
\hline Average & 59.65 & \pm & 3.91 & A & 54.26 & \pm & 3.68 & B & 47.38 & \pm & 3.23 & C & 54.80 & \pm & 4.29 & B & 51.88 & \pm & 3.72 & B \\
\hline
\end{tabular}

Within each season, most of the fruit quality parameters showed a significant variation between harvest times (Table 3). However, there were exceptions depending on the variety and the parameter considered. Thus, a generalized trend towards lower firmness, TSS and TSS/acidity values was observed in all varieties as the season progressed, while the reverse was true for acidity and for the total phenolic and anthocyanin content, consistently with Taghavi et al. [49]. Only in 'Splendor' did the TSS and TSS/acidity values not vary significantly (Table 3). The decrease in TSS and TSS/acidity in strawberry throughout the season has been attributed to the increase in temperature resulting in an increase in the respiration rate and, consequently, decreasing the content of sugars, organic acids 
and soluble solids of the fruits [50-52]. On the other hand, total flavonoid and vitamin C fruit content did not show significant variation throughout the season in any of the study varieties, except in 'Sabrina', with lower values of vitamin C as the season progressed (Table 3). Finally, the antioxidant capacity of the fruits (TEAC) increased significantly from the beginning of the season in 'Splendor', 'Fortuna' and 'Primoris', while in Candonga ${ }^{\circledR}$ and 'Sabrina', no significant variation was found (Table 3). These results indicate that the environmental variation during the cropping season does not affect fruit quality parameters and strawberry varieties in the same way.

Table 3. Intra-annual variation of the organoleptic and functional fruit quality parameters in the five strawberry varieties. Each value is the mean \pm SE for each harvest time regardless of the year. On each variety, letters indicate significant differences $(p<0.05)$ between harvest times.

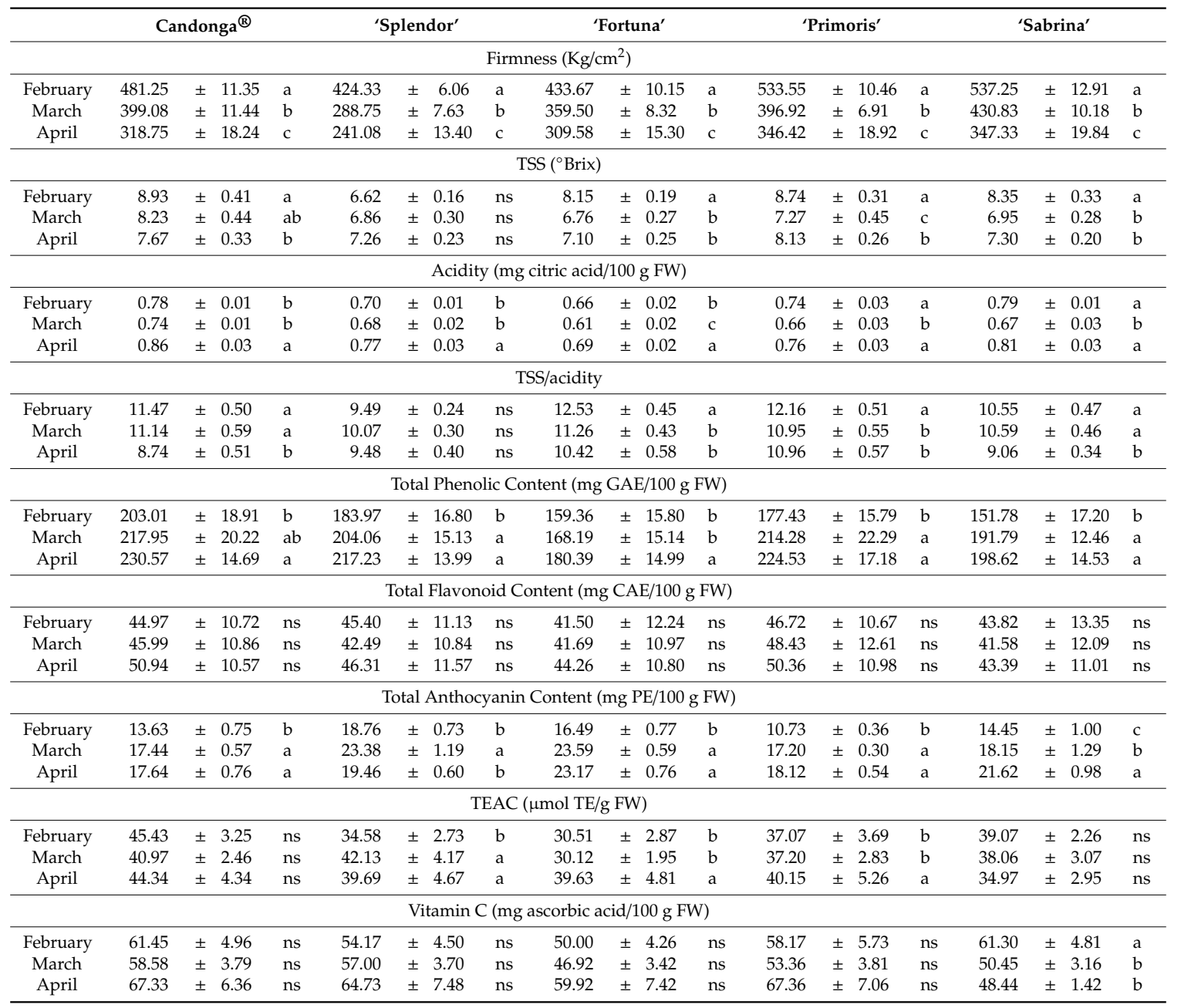

In previous studies on strawberries and other berries, the variation of fruit quality parameters throughout the season has been associated with the increasing photoperiod and/or temperatures towards the end of the season $[16,37,53]$. However, in these works, there are inconsistencies regarding the relative contribution of environmental factors and about the acting mechanisms for explaining the trends of fruit quality variation. For instance, some authors reported the degradation of fruit anthocyanin content at the end of the season due to photoinhibition and the highest photoperiod [54], while others observed anthocyanin accumulation at the end of the season as a result of the higher temperatures [53,55]. On the other hand, Wang and Zheng [16] observed higher content of numerous phenolic compounds and antioxidant capacity as temperature increased, and Lee and Kader [56] suggested a direct effect of light on Vitamin C formation in horticultural crops. 
Therefore, due to the complexity of the interactions between the factors determining crop development [57,58], it is difficult to identify a single environmental factor accounting for the observed variability.

In our study, although fruit quality parameters generally displayed consistent trends across varieties, a more exhaustive analysis of their relationship with the environmental variation (i.e., temperature, relative humidity, and incident radiation) on each genotype is required for a better understanding of the genotype-environment interaction and its effect on fruit quality traits.

Pearson's correlation and stepwise multiple regression analyses were performed to discriminate those environmental variables explaining the greater amount of the variability in fruit quality parameters observed throughout the season. Most of them were significantly correlated with the environmental variables in all varieties (data not shown), but the regression models fitted revealed that their environmental dependence was not similar in all cases. Overall, mean temperature (Tmed), minimum temperature (Tmin) and relative humidity $(\mathrm{RH})$ were the environmental variables that, to some extent, accounted for the observed variation of fruit quality parameters in all varieties.

Thus, a very strong and negative relationship was observed between Tmed and fruit firmness in all varieties $\left(0.63<R^{2}<0.75\right.$; Table 4$)$, which is consistent with previous reports on strawberries and other fruits $[59,60]$. Fruit firmness is a complex phenomenon whose mechanism is not fully understood, although it has been associated with increased enzymatic activity and loss of turgor in fruit cells with increasing temperature [61,62]. It is noteworthy that, despite the firmness's dependence on the environment, the differences between varieties remain consistently, which underlines its use as a selection criterion in breeding programs [63]. On the contrary, little or no dependence was found between environmental variables and TSS and Vitamin C, which suggests that other variables not considered in this work should account for the variation observed in these parameters.

For the remaining parameters, although the fitted models revealed a significant $(p<0.05)$ relationship with some environmental variables, the percentage of variation explained by the environment was rather low $\left(R^{2}<0.50\right)$, with some exceptions in 'Sabrina', 'Fortuna' and 'Primoris' (Table 4). In 'Sabrina', Tmin was negatively and positively related with TSS/acidity ( flavor) and phenolic content, respectively $\left(R^{2}=0.55\right.$ and $\left.R^{2}=0.51\right)$, suggesting a greater dependence of this variety on Tmin. This is consistent with the increase in phenolic compounds towards the end of the season, which is in agreement with previous reports on strawberries and other berries [16,64]. In 'Primoris' and 'Fortuna', there was a remarkable relationship between anthocyanin content and Tmax and Tmed, respectively $\left(R^{2}=0.62\right.$ and $\left.R^{2}=0.55\right)$, while the other fruit quality parameters showed a significant relationship with relative humidity $(\mathrm{RH})$, which was stronger for the fruit phenolic content in 'Fortuna' $\left(R^{2}=0.54 ;\right.$ Table 4$)$.

In Candonga ${ }^{\circledR}$ and 'Splendor', the relationship between the variation of fruit quality parameters and the environmental variables was weaker, and $\mathrm{RH}$ was the environmental variable that mostly correlated with functional quality parameters, except for anthocyanins, whose variation was associated with temperature in Candonga ${ }^{\circledR}$ (Table 4 ).

It is remarkable that, in all varieties, $\mathrm{RH}$ was the main variable explaining, to a certain extent, the variation in flavonoids (positive relationship) and TEAC (negative relationship) (Table 4). In this sense, the relative humidity can affect cell turgor and fruit water content [60] and, consequently, the proportion of antioxidant compounds per unit of fresh weight. The slight relationship between $\mathrm{RH}$ and flavonoids but consistent across all varieties suggests that RH may influence their biosynthesis, which would be in consonance with the flavonoid increase observed in strawberries during storage at high humidity [65]. It should be noted that the relationship between RH and TEAC was opposite to that of RH and total phenolic content (Table 4), pointing out once again that other non-phenolic compounds are contributing to the fruits antioxidant capacity (TEAC). 
Table 4. Coefficients of the fitted linear regression models $(Y=a X+\beta)$ after stepwise multiple regression between fruit quality parameters (organoleptic and functional) and environmental variables in the five varieties studied. All models fitted were significant $(p<0.05)$ and the values of the coefficient of determination $\left(\mathrm{R}^{2}\right)$ are shown.

\begin{tabular}{|c|c|c|c|c|c|c|c|c|c|c|}
\hline & & \multicolumn{4}{|c|}{ Organoleptic Parameters } & \multicolumn{5}{|c|}{ Functional Parameters } \\
\hline & & Firmness & TSS & Acidity & TSS/Acidity & TPC $^{1}$ & TFC & TAC & TEAC & Vit $C$ \\
\hline \multirow[t]{7}{*}{ Candonga ${ }^{\circledR}$} & $\beta$ & 705.82 & - & - & 13.26 & -53.79 & -42.60 & 12.69 & 94.64 & - \\
\hline & Tmin & & - & - & -0.586 & - & - & 0.52 & - & - \\
\hline & Tmax & & - & - & - & - & - & - & - & - \\
\hline & Tmed & -0.821 & - & - & - & - & - & - & - & - \\
\hline & $\mathrm{RH}$ & & - & - & - & 0.58 & 0.46 & - & -0.63 & - \\
\hline & Radiation & & - & - & - & - & - & - & - & - \\
\hline & $\mathrm{R}^{2}$ & 0.67 & - & - & 0.32 & 0.32 & 0.18 & 0.25 & 0.37 & - \\
\hline \multirow[t]{7}{*}{ 'Splendor' } & $\beta$ & 652.41 & - & 0.54 & 10.52 & -53.45 & -95.93 & - & 108.497 & - \\
\hline & Tmin & - & - & - & -0.334 & - & - & - & - & - \\
\hline & Tmax & - & - & - & - & - & - & - & - & - \\
\hline & Tmed & -0.867 & - & 0.497 & - & - & - & - & - & - \\
\hline & $\mathrm{RH}$ & - & - & - & - & 0.59 & 0.49 & - & -0.61 & - \\
\hline & Radiation & - & - & - & - & - & - & - & - & - \\
\hline & $R^{2}$ & 0.75 & - & 0.22 & 0.09 & 0.10 & 0.22 & - & 0.35 & - \\
\hline \multirow[t]{7}{*}{ 'Fortuna' } & $\beta$ & 602.23 & - & 0.3374 & 18.95 & -127.22 & -98.82 & 7.42 & 11.48 & -4.47 \\
\hline & Tmin & - & - & - & - & - & - & - & - & - \\
\hline & Tmax & - & - & - & - & - & - & - & - & - \\
\hline & Tmed & -0.798 & - & - & - & - & - & 0.75 & - & - \\
\hline & $\mathrm{RH}$ & - & - & 0.551 & -0.520 & 0.74 & 0.49 & - & - & 0.38 \\
\hline & Radiation & - & - & - & - & - & - & - & 0.43 & - \\
\hline & $R^{2}$ & 0.63 & - & 0.28 & 0.25 & 0.54 & 0.21 & 0.55 & 0.16 & 0.12 \\
\hline \multirow[t]{7}{*}{ 'Primoris' } & $\beta$ & 858.42 & 12.61 & - & 19.96 & 111.54 & -101.99 & -0.95 & 97.03 & - \\
\hline & Tmin & - & - & - & - & 0.63 & - & - & - & - \\
\hline & Tmax & - & - & - & - & - & - & 0.80 & - & - \\
\hline & Tmed & -0.85 & - & - & - & - & - & - & - & - \\
\hline & RH & - & -0.47 & - & -0.61 & - & 0.53 & - & -0.56 & - \\
\hline & Radiation & - & - & - & - & - & - & - & - & - \\
\hline & $\mathrm{R}^{2}$ & 0.71 & 0.20 & - & 0.35 & 0.38 & 0.26 & 0.62 & 0.29 & - \\
\hline \multirow[t]{7}{*}{ 'Sabrina' } & $\beta$ & 797.93 & - & - & 19.063 & 95.75 & -98.27 & -6.05 & 76.63 & - \\
\hline & Tmin & - & - & - & -0.75 & 0.72 & - & - & - & - \\
\hline & Tmax & - & - & - & - & - & - & - & - & - \\
\hline & Tmed & -0.85 & - & - & - & - & - & - & - & - \\
\hline & RH & - & - & - & - & - & 0.48 & 0.65 & -0.60 & - \\
\hline & Radiation & - & - & - & - & - & - & & & - \\
\hline & $R^{2}$ & 0.71 & - & - & 0.55 & 0.51 & 0.21 & 0.41 & 0.34 & - \\
\hline
\end{tabular}

${ }^{1}$ TPC: Total phenol content; TFC: Total flavonoid content; TAC: Total anthocyanin content.

Taking into account the values of determination coefficients $\left(R^{2}\right)$ explaining a considerable percentage of the observed variation in fruit quality parameters (i.e., $R^{2}>0.50$ ), it could be pointed out that fruit quality of 'Sabrina' and 'Fortuna' is more dependent upon the environmental variation than that of 'Primoris', 'Splendor' and Candonga ${ }^{\circledR}$.

Overall, the results of the present study showed that the variation of fruit quality parameters throughout the season (intra-annual) did not necessarily match their year-on-year stability (inter-annual) on each strawberry variety (Figure 1) and that environmental influence on organoleptic and functional fruit quality traits is genotype-dependent. 
(a)

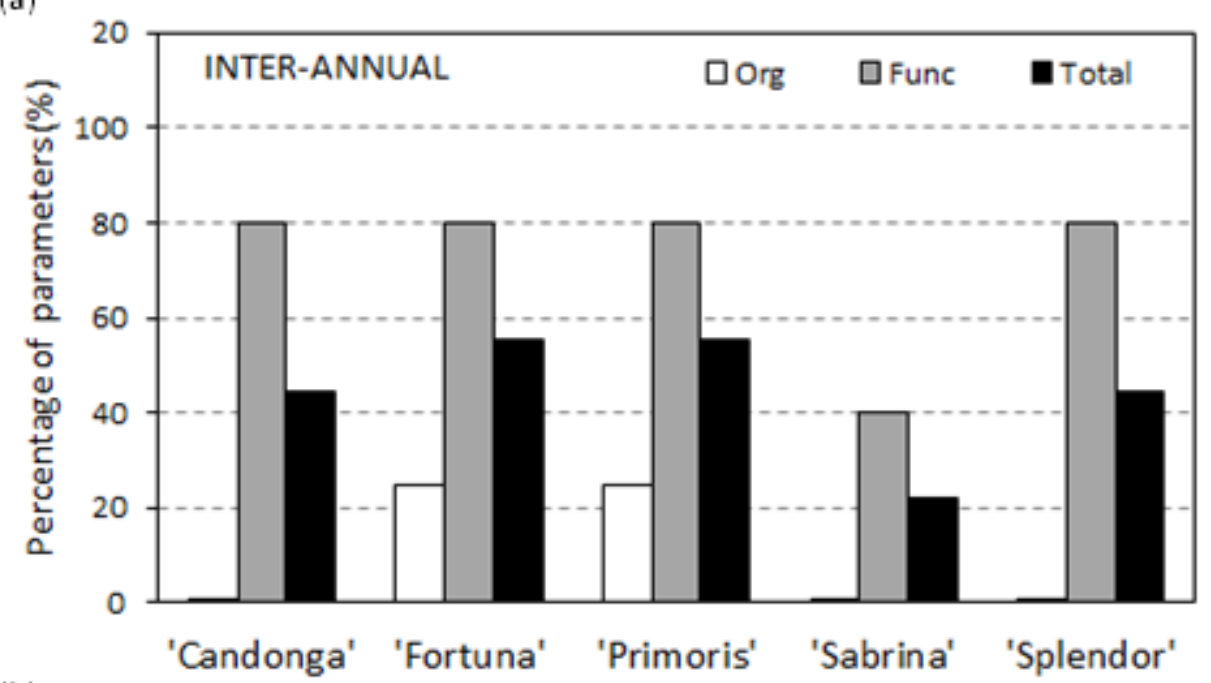

(b)

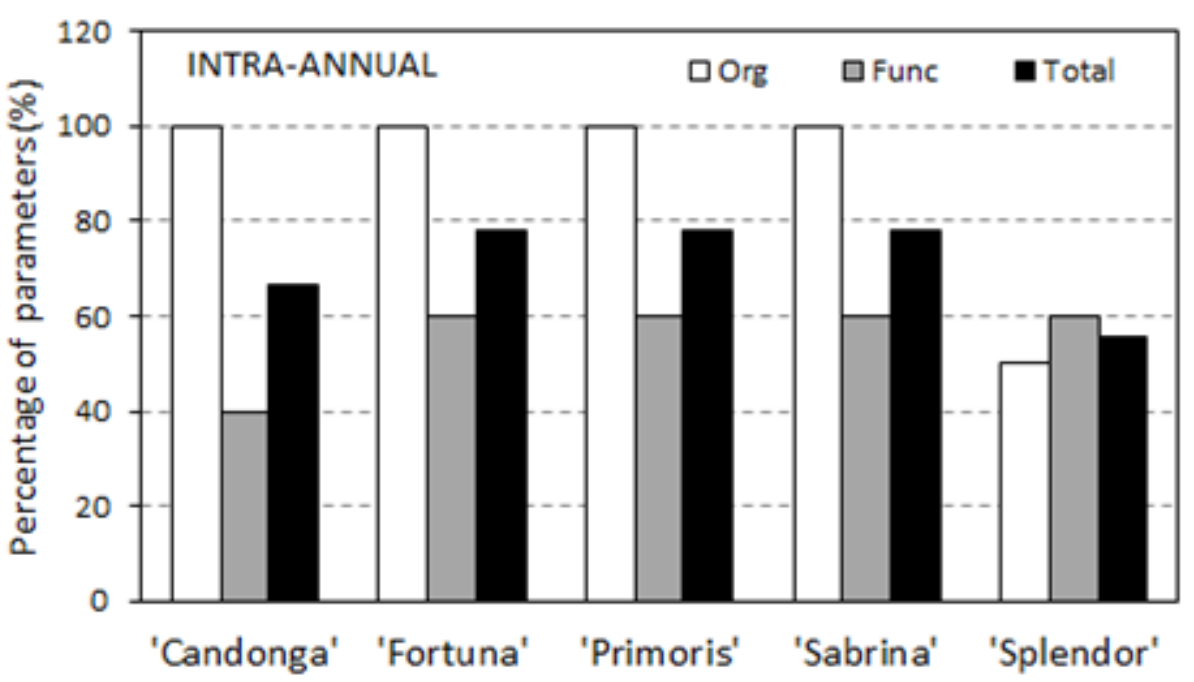

Figure 1. Percentage of organoleptic (Org) and functional (Func) fruit quality parameters showing significant inter- $(\mathbf{a})$ and intra- $(\mathbf{b})$ annual variation $(p<0.05)$ in the five strawberry varieties studied.

\section{Conclusions}

Fruit quality is a complex concept that includes organoleptic and functional attributes (i.e., health benefits) highly appreciated by consumers. It, therefore, comprises different types of parameters which, depending on the genotype, may be affected to a different extent by environmental variations. Knowledge of the relative stability of fruit quality traits in different genotypes is important for selecting parents and genotypes in strawberry breeding programs.

This work shows that strawberry organoleptic and functional fruit quality parameters evaluated in this study have a contrasting pattern of inter- and intra-annual variation. Thus, organoleptic characters considered in this study hardly varied year-on-year, while they showed great variability throughout the season in most varieties studied, except in 'Splendor', which displayed greater stability in these characters (i.e., lower percentage of organoleptic parameters with significant intra-annual variation; Figure 1). In contrast, functional fruit quality traits showed greater year-on-year variation in all varieties, 'Sabrina' displaying higher stability, whereas the reverse was true for the variation throughout the season, being less remarkable in Candonga ${ }^{\circledR}$.

This dichotomy was kept in the different genotypes, hindering the selection of a genotype with stability at the inter- and intra-annual levels in organoleptic and functional fruit quality parameters. 
In this sense, among the three varieties with greater stability, 'Splendor', 'Sabrina' and Candonga ${ }^{\circledR}$, fruit quality values in the latter were always among the highest (or not significantly different from other varieties), while in 'Splendor', even though organoleptic parameters were more stable, their values were lower than in most varieties. It is also noteworthy that, in 'Sabrina' and Candonga ${ }^{\circledR}$, TEAC did not vary throughout the season and values were among the highest. These results suggest that these two varieties may be good candidates for parents in breeding programs that seek high-quality fruits meeting consumer demands.

Finally, fruit quality variation in the different strawberry varieties was only partially dependent upon the environmental variables, among which $\mathrm{RH}$ and Tmin were notable, suggesting that, along with the genotype, other environmental factors not considered in this study may account for it.

Author Contributions: M.T.A., E.M.-F., L.C. conceptualization, data collection, data evaluation, main writing, structuring of original draft, review, editing, and supervision; C.S. conceptualization, data collection and data evaluation; L.M., J.J.M. data collection; D.L. review and editing. All authors have read and agreed to the published version of the manuscript.

Funding: This research was funded by the INIA-RTA2017-00014, AVA2016.01.10 and AVA2019.034 projects co-financed by the FEDER funds (UE) within the "Programa Operativo de Andalucía 2014-2020". M.T. Ariza is hired by IFAPA, Junta de Andalucía (20\%) and by the "Programa Operativo Fondo Social Europeo (FSE) de Andalucía 2007-2013 (80\%)" under the topic "Andalucía se mueve con Europa". Lucía Cervantes is supported by a MINECO contract for the promotion of youth employment. David Lozano is employed under the State Programme for the Promotion of Talent and its Employability under the State Plan for Scientific and Technical Research and Innovation 2013-2016 (DOC-INIA) co-financed by INIA and the European Social Fund (ESF).

Acknowledgments: We thank all the farm workers for their collaboration on the field trials.

Conflicts of Interest: The authors declare no conflict of interest.

\section{References}

1. Kader, A. Importance of fruits, nuts, and vegetables in human nutrition and health. Perish. Hand. Q. 2001, 106,6 .

2. Afrin, S.; Giampieri, F.; Gasparrini, M.; Forbes-Hernandez, T.; Varela-López, A.; Quiles, J.; Mezzetti, B.; Battino, M. Chemopreventive and therapeutic effects of edible berries: A focus on colon cancer prevention and treatment. Molecules 2016, 21, 169. [CrossRef]

3. Skrovankova, S.; Sumczynski, D.; Mlcek, J.; Jurikova, T.; Sochor, J. Bioactive compounds and antioxidant activity in different types of berries. Int. J. Mol. Sci. 2015, 16, 24673-24706. [CrossRef]

4. Ariza, M.T.; Martínez-Ferri, E.; Domínguez, P.; Medina, J.J.; Miranda, L.; Soria, C. Effect of harvest time on functional compounds and fruit antioxidant capacity in ten strawberry cultivars. J. Berry Res. 2015, 5, 71-80. [CrossRef]

5. Scalzo, J.; Politi, A.; Pellegrini, N.; Mezzetti, B.; Battino, M. Plant genotype affects total antioxidant capacity and phenolic contents in fruit. Nutrition 2005, 21, 207-213. [CrossRef] [PubMed]

6. Cordenunsi, B.R.; Oliveira do Nascimento, J.R.; Genovese, M.I.; Lajolo, F.M. Influence of cultivar on quality parameters and chemical composition of strawberry fruits grown in Brazil. J. Agric. Food Chem. 2002, 50, 2581-2586. [CrossRef] [PubMed]

7. Ariza, M.T.; Soria, C.; Medina-Mínguez, J.J.; Martínez-Ferri, E. Incidence of misshapen fruits in strawberry plants grown under tunnels is affected by cultivar, planting date, pollination, and low temperatures. Hortscience 2012, 47, 1569-1573. [CrossRef]

8. Ariza, M.T.; Soria, C.; Medina, J.J.; Martinez-Ferri, E. Fruit misshapen in strawberry cultivars $($ Fragaria $\times$ ananassa) is related to achenes functionality. Ann. Appl. Biol. 2011, 158, 130-138. [CrossRef]

9. Heide, O.M. Photoperiod and temperature interactions in growth and flowering of strawberry. Physiol. Plant. 1977, 40, 21-26. [CrossRef]

10. Lattanzio, V.; Kroon, P.A.; Quideau, S.; Treutter, D. Plant phenolics-secondary metabolites with diverse functions. Rec. Adv. Polyphen. Res. 2008, 1, 1-35.

11. Bian, Z.H.; Yang, Q.C.; Liu, W.K. Effects of light quality on the accumulation of phytochemicals in vegetables produced in controlled environments: A review. J. Sci. Food Agric. 2015, 95, 869-877. [CrossRef] [PubMed] 
12. Pardossi, A.; Giacomet, P.; Malorgio, F.; Albini, F.M.; Murelli, C.; Serra, G.; Vernieri, P. The influence of growing season on fruit yield and quality of greenhouse melon (Cucumis melo L.) grown in nutrient film technique in a Mediterranean climate. J. Hortic. Sci. Biotechnol. 2000, 75, 488-493. [CrossRef]

13. Shinohara, Y. Growing conditions and quality of vegetables: Effect of light and fertilizer conditions on the ascorbic acid content of vegetables. Memoirs of Institute of Agriculture and Forestry-University of Tsukuba. Agric. For. Sci. 1987, 3, 61-156.

14. Wang, S.; Camp, M. Temperatures after bloom affect plant growth and fruit quality of strawberry. Sci. Hortic. 2000, 85, 183-199. [CrossRef]

15. Kadir, S.; Sidhu, G.; Al-Khatib, K. Strawberry (Fragaria $x$ ananassa Duch.) growth and productivity as affected by temperature. HortScience 2006, 41, 1423-1430. [CrossRef]

16. Wang, S.Y.; Zheng, W. Effect of plant growth temperature on antioxidant capacity in strawberry. J. Agric. Food Chem. 2001, 49, 4977-4982. [CrossRef]

17. Davik, J.; Bakken, A.K.; Holte, K.; Blomhoff, R. Effects of genotype and environment on total anti-oxidant capacity and the content of sugars and acids in strawberries (Fragaria $\times$ ananassa Duch.). J. Hortic. Sci. Biotechnol. 2006, 81, 1057-1063. [CrossRef]

18. Leonardi, C.; Guichard, S.; Bertin, N. High vapour pressure deficit influences growth, transpiration and quality of tomato fruits. Sci. Hortic. 2000, 84, 285-296. [CrossRef]

19. Tulipani, S.; Marzaban, G.; Herndl, A.; Laimer, M.; Mezzetti, B.; Battino, M. Influence of environmental and genetic factors on health-related compounds in strawberry. Food Chem. 2011, 124, 906-913. [CrossRef]

20. Palmieri, L.; Masuero, D.; Martinatti, P.; Baratto, G.; Martens, S.; Vrhovsek, U. Genotype-by-environment effect on bioactive compounds in strawberry (Fragaria x ananassa Duch.). Sci. Food Agric. 2017, 97, 4180-4189. [CrossRef]

21. Mezzetti, B.; Giampieri, F.; Zhang, Y.T.; Zhong, C.F. Status of strawberry breeding programs and cultivation systems in Europe and the rest of the world. J. Berry Res. 2018, 8, 205-221. [CrossRef]

22. Vicente, E.; Giménez, G.; Manzzioni, A.; Vilaró, F.; González, M.; Cabot, M. Strawberry breeding in Uruguay. Acta Hortic. 2009, 842, 411-414. [CrossRef]

23. Shaw, D.V.; Larson, K.D. Performance of early-generation and modern strawberry cultivars from the University of California breeding programme in growing systems simulating traditional and modern horticulture. J. Hortic. Sci. Biotechnol. 2008, 83, 648-652. [CrossRef]

24. Faedi, W.; Mourgues, F.; Rosati, C. Strawberry breeding and varieties: Situation and perspectives. Acta Hortic. 2002, 567, 51-59. [CrossRef]

25. Mezzetti, B.; Balducci, F.; Capocasa, F.; Zhong, C.F.; Cappelletti, R.; Di Vittori, L.; Mazzoni, L.; Giampieri, F.; Battino, M. Breeding strawberry for higher phytochemicals content and claim it: Is it possible? Int. J. Fruit Sci. 2016, 16, 194-206. [CrossRef]

26. López Aranda, J.M. The cultivation of the strawberry in Huelva. In The Strawberry Crop at Huelva; de Andalucía, J., Ed.; Ideas, Exclusivas y Publicidad S.L.: Sevilla, Spain, 2008; pp. 101-174.

27. Domínguez, P.; Miranda, L.; Soria, C.; De los Santos, B.; Chamorro, M.; Romero, F.; Daugovish, O.; López-Aranda, J.M.; Medina, J.J. Soil biosolarization for sustainable strawberry production. Agron. Sustain. Dev. 2014, 34, 821-829. [CrossRef]

28. RIA, Red Información Agroclimática de Andalucía. Available online: https:/ifapa.junta-andalucia.es/ agriculturaypesca/ifapa/ria/servlet/FrontController (accessed on 12 November 2019).

29. Singleton, V.L.; Orthofer, R.; Lamuela-Raventos, R.M. Analysis of total phenols and other oxidation substrates and antioxidants by means of Folin-Ciocalteu reagent. Methods Enzymol. 1999, 299, 152-178. [CrossRef]

30. Tulipani, S.; Mezzetti, B.; Capocasa, F.; Bompadre, S.; Beekwilder, J.; De Vos, C.R.; Capanoglu, E.; Bovy, A.; Battino, M. Antioxidants, phenolic compounds, and nutritional quality of different strawberry genotypes. J. Agric. Food Chem. 2008, 56, 696-704. [CrossRef]

31. Dewanto, V.; Wu, X.; Adom, K.K.; Liu, R.H. Thermal processing enhances the nutritional value of tomatoes by increasing total antioxidant activity. J. Agric. Food Chem. 2002, 50, 3010-3014. [CrossRef]

32. Giusti, M.M.; Wrolstad, R.E. Characterization and measurement of anthocyanins by UV-visible spectroscopy. In Current Protocols in Food Analytical Chemistry; Wrolstad, R.E., Ed.; Wiley: New York, NY, USA, 2001. [CrossRef]

33. Re, R.; Pellegrini, N.; Proteggente, A.; Pannala, A.; Yang, M.; Rice-Evans, C. Antioxidant activity applying an improved ABTS radical cation decolorization assay. Free Radic. Biol. Med. 1999, 26, 1231-1237. [CrossRef] 
34. Desboulets, L.D.D. A review on variable selection in regression analysis. Econometrics 2018, 6, 45. [CrossRef]

35. Breaux, H.J. On Stepwise Multiple Linear Regression; Technical Report No. BRL-1369; US Army Material Command Ballistic Research Laboratories: Aberdeen, MD, USA, 1967.

36. Fait, A.; Hanhineva, K.; Beleggia, R.; Dai, N.; Rogachev, I.; Nikiforova, V.J.; Fernie, A.R.; Aharoni, A. Reconfiguration of the achene and receptacle metabolic networks during strawberry fruit development. Plant Physiol. 2008, 148, 730-750. [CrossRef] [PubMed]

37. Akhatou, I.; Fernández-Recamales, A. Nutritional and nutraceutical quality of strawberries in relation to harvest time and crop conditions. J. Agric. Food Chem. 2014, 62, 5749-5760. [CrossRef]

38. Capocasa, F.; Scalzo, J.; Mezzetti, B.; Battino, M. Combining quality and antioxidant attributes in the strawberry: The role of genotype. Food Chem. 2008, 111, 872-878. [CrossRef]

39. Diamanti, D.; Capocasa, F.; Denoyes, B.; Petit, A.; Chartier, P.; Faedi, W.; Maltoni, M.L.; Battino, M.; Mezzetti, B. Standardized method for evaluation of strawberry (Fragaria ananassa Duch.) germplasm collections as a genetic resource for fruit nutritional compounds. J. Food Compos. Anal. 2012, 28, 170-178. [CrossRef]

40. Crespo, P.; Bordonana, J.G.; Terry, L.A.; Carlen, C. Characterisation of major taste and health-related compounds of four strawberry genotypes grown at different Swiss production sites. Food Chem. 2010, 122, 16-24. [CrossRef]

41. Jouquand, C.; Chandler, C.; Plotto, A.; Goodner, K. A sensory and chemical analysis of fresh strawberries over harvest dates and seasons reveals factors that affect eating quality. J. Am. Soc. Hortic. Sci. 2008, 133, 859-867. [CrossRef]

42. Di Ferdinando, M.; Brunetti, C.; Agati, G.; Tattini, M. Multiple functions of polyphenols in plants inhabiting unfavorable Mediterranean areas. Environ. Exp. Bot. 2014, 103, 107-116. [CrossRef]

43. Gulcin, İ. Antioxidants and antioxidant methods: An updated overview. Arch. Toxicol. 2020, 94, 651-715. [CrossRef]

44. Gulcin, İ. Antioxidant activity of food constituents: An overview. Arch. Toxicol. 2012, 86, 345-391. [CrossRef]

45. MacDonald-Wicks, L.K.; Wood, L.G.; Garg, M.L. Methodology for the determination of biological antioxidant capacity in vitro: A review. J. Sci. Food Agric. 2006, 86, 2046-2056. [CrossRef]

46. Manganaris, G.A.; Goulas, V.; Vicente, A.R.; Terry, L.A. Berry antioxidants: Small fruits providing large benefits. J. Sci. Food Agric. 2013, 94, 825-833. [CrossRef] [PubMed]

47. Puchau, B.; Zulet, M.Á.; de Echávarri, A.G.; Hermsdorff, H.H.M.; Martínez, J.A. Dietary total antioxidant capacity: A novel indicator of diet quality in healthy young adults. J. Am. Coll. Nutr. 2009, 28, 648-656. [CrossRef] [PubMed]

48. Capocasa, F.; Diamanti, J.; Tulipani, S.; Battino, M.; Mezzetti, B. Breeding strawberry (Fragaria $\times$ ananassa Duch.) to increase fruit nutritional quality. Biofactors 2008, 34, 67-72. [CrossRef] [PubMed]

49. Taghavi, T.; Siddiqui, R.; Rutto, L.K. The effect of preharvest factors on fruit and nutritional quality in strawberry. In Strawberry-Pre-and Post-Harvest Management Techniques for Higher Fruit Quality; Asao, T., Ed.; IntechOpen: London, UK, 2019. [CrossRef]

50. Ruan, J.; Lee, Y.H.; Hong, S.J.; Yeoung, Y.R. Sugar and organic acid contents of day-neutral and ever-bearing strawberry cultivars in high-elevation for summer and autumn fruit production in Korea. Hortic. Environ. Biotechnol. 2013, 54, 214-222. [CrossRef]

51. Mackenzie, S.J.; Chandler, C.K.; Hasing, T.; Whitaker, V.M. The role of temperature in the late-season decline in soluble solids content of strawberry fruit in a subtropical production system. Hortic. Sci. 2011, 46, 1562-1566. [CrossRef]

52. Shaw, D.V. Genotypic variation and genotypic correlations for sugars and organic acids of strawberries. J. Am. Soc. Hortic. Sci. 1988, 113, 770-774.

53. Zoratti, L.; Jaakola, L.; Häggman, H.; Giongo, L. Anthocyanin profile in berries of wild and cultivated Vaccinium spp. along altitudinal gradients in the Alps. J. Agric. Food Chem. 2015, 63, 8641-8650. [CrossRef]

54. Cardeñosa, V.; Girones-Vilaplana, A.; Muriel, J.L.; Moreno, D.A.; Moreno-Rojas, J.M. Influence of genotype, cultivation system and irrigation regime on antioxidant capacity and selected phenolics of blueberries (Vaccinium corymbosum L.). Food Chem. 2016, 202, 276-283. [CrossRef]

55. Zoratti, L.; Jaakola, L.; Häggman, H.; Giongo, L. Modification of sunlight radiation through colored photo-selective nets affects anthocyanin profile in Vaccinium spp. berries. PLoS ONE 2015, 10, e0135935. [CrossRef] 
56. Lee, S.; Kader, A.A. Preharvest and postharvest factors influencing vitamin C content of horticultural crops. Postharvest Biol. Technol. 2000, 20, 207-220. [CrossRef]

57. Uleberg, E.; Rohloff, J.; Jaakola, L.; Trôst, K.; Junttila, O.; Häggman, H.; Martinussen, I. Effects of temperature and photoperiod on yield and chemical composition of northern and southern clones of bilberry (Vaccinium myrtillus L.). J. Agric. Food Chem. 2012, 60, 10406-10414. [CrossRef] [PubMed]

58. Remberg, S.F.; Sønsteby, A.; Aaby, K.; Heide, O.M. Influence of postflowering temperature on fruit size and chemical composition of Glen Ample raspberry (Rubus idaeus L). J. Agric. Food Chem. 2010, 58, 9120-9128. [CrossRef] [PubMed]

59. Agüero, J.J.; Salazar, S.M.; Kirschbaum, D.S.; Jerez, E.F. Factors affecting fruit quality in strawberries grown in a subtropical environment. Int. J. Fruit Sci. 2015, 15, 223-234. [CrossRef]

60. Sams, C.E. Preharvest factors affecting postharvest texture. Postharvest Biol. Technol. 1999, 15, $249-254$. [CrossRef]

61. Pyrotis, S.; Abayomi, L.; Rees, D.; Orchard, J. Effect of temperature and humidity on strawberry firmness at two different sites in the Huelva region of Spain. Acta Horti. 2012, 926, 567-570. [CrossRef]

62. Van Dijk, C.; Boeriu, C.; Peter, F.; Stolle-Smits, T.; Tijskens, L.M.M. The firmness of stored tomatoes (cv. Tradiro). 1. Kinetic and near infrared models to describe firmness and moisture loss. J. Food Eng. 2006, 77, 575-584. [CrossRef]

63. Salentijn, E.M.; Aharoni, A.; Schaart, J.G.; Boone, M.J.; Krens, F.A. Differential gene expression analysis of strawberry cultivars that differ in fruit-firmness. Physiol. Plant. 2003, 118, 571-578. [CrossRef]

64. Krüger, E.; Dietrich, H.; Hey, M.; Patz, C.D. Effects of cultivar, yield, berry weight, temperature and ripening stage on bioactive compounds of black currants. J. Appl. Bot. Food Qual. 2011, 84, 40-46.

65. Shin, Y.; Liu, R.H.; Nock, J.F.; Holliday, D.; Watkins, C.B. Temperature and relative humidity effects on quality, total ascorbic acid, phenolics and flavonoid concentrations, and antioxidant activity of strawberry. Postharvest Biol. Technol. 2007, 45, 349-357. [CrossRef]

(C) 2020 by the authors. Licensee MDPI, Basel, Switzerland. This article is an open access article distributed under the terms and conditions of the Creative Commons Attribution (CC BY) license (http://creativecommons.org/licenses/by/4.0/). 